\title{
Shale Symposium at the International Congress of the ISRM Montreal, Canada May 10-13, 2015
}

\author{
Herbert H. Einstein ${ }^{1}$
}

Received: 6 October 2015/Accepted: 6 October 2015/Published online: 20 October 2015

(C) Springer-Verlag Wien 2015

The Canadian Rock Mechanics Association (CARMA) and the American Rock Mechanics Association (ARMA) together with the leadership of the Congress under Professor Hassani organized a special "Shale Symposium" at the International Congress of the International Society for Rock Mechanics (ISRM). This symposium, which ran during four half days during the 3-day Congress, was structured in three topic areas with corresponding sessions: "Basics and Slopes", "Mining and Tunnels", "Hydrocarbon". An additional session was devoted to a debate on "Shale is a Soft Rock, not a Hard Soil". Each of the topic sessions started and ended with a keynote paper. The keynote papers were substantially revised, and the revised versions were peer reviewed for publication in this special issue following this editorial. A few comments about the topics covered in each session are provided here:

In Basics and Slopes most of the papers dealt with basic mechanical and mineralogical properties of shales, and the majority of papers did so based on laboratory tests and field observations while a few concentrated on numerical modeling. Mining and Tunneling papers not only presented a variety of case studies but also some work on fundamental aspects that need to be considered. Not surprisingly many of the case studies relate to radioactive waste repositories. As to be expected the Hydrocarbon session was the one with the largest number of papers. There was a good mix of topics, ranging from simulation (modeling) to laboratory and field experiments, including several papers that combined modeling and experimentation. The papers are listed in the list of references at the end of this editorial.

\footnotetext{
Herbert H. Einstein

einstein@mit.edu

1 Cambridge, MA 02139, USA
}

As indicated above, the Symposium also included the debate on the "motion" "Shale is a Soft Rock, not a Hard Soil". Debaters for the motion were Derek Elsworth and Priscilla Nelson; debating against were John McLennan and Maurice Dusseault. The debate started with a short formal argument by each debater, followed by informal replies by all debaters, questions from the audience to the debaters and an open discussion within the audience. It ended with a vote, which after an initial vote with equal numbers of votes for and against, ended with the nearly unanimous vote for Mark Zoback's proposal. "Shale is both a soft rock and a hard soil".

This is a very appropriate introduction to the Special Issue since it reflects both the basic properties of the material and the engineering consequences.

\section{List of References}

As indicated in the summary above the following is a list of all the papers that were presented at the Symposium and are included in the Proceedings of the International Congress of the ISRM. Note again that the keynote papers have been rewritten for this special issue.

\subsection{Basics and Slopes}

\section{Stead, D. KEYNOTE}

The Influence of Shales on Slope Instability

Jin, W.; Xu, H.; Arson, C.

Energy Dissipation During Mode I Fracture Propagation in Shale: Comparison Between a Continuum Damage Model, a Cohesive Zone Model and the Extended Finite Element Method 
Guglielmi, Y.; Henry, P.; Gout, C.; Dick, P.

Field Experiments of Fault Activation in Shales

Zhang, F.; Chorney, D.; Grob, M.; Maxwell, S.

Effects of Hydraulic of Fracture Crossing Natural Fractures: Numerical Study Using Hybrid Discrete-Continuum Modeling

Fityus S.G.; Jeffery, M.; Aglias, K.J.; Johnston, J.A.

Weathering and Degradation of Shales and Mudrocks

Wang, D.; Ge, H.; Wang, X.; Wang, J.; Meng, F.

The Mechanical Properties of Gas Shale Under Uniaxial Stress Moradian, Z.; Li, Q.B.; Morgan, S.; Gonçalves da Silva, B. Germaine, J.T.; Einstein, H.H.

Acoustic Emission Characteristics of Shale

Amann, F.; Wild, K.M.; Martin, C.D.

The Role of Capillary Suction and Dilatancy on the Interpretation of the Confined Strength of Clay Shales

Ambrose, J.; Zimmerman, R.W.

Failure of Anisotropic Shales Under Triaxial Compression and Extension

Carvalho, J. L.

A Simple Numerical Approach for Modelling Time Dependent Swelling Mechanisms in Shales

Gautam, T.P.; Shakoor, A.

Assessing the Long-Term Slaking Behavior of ClayBearing Rocks

Meléndez-Martínez, J.; Schmitt, D.R.; Ong, N.; Kofman, R.S.

Static, Dynamic, and Stress Dependent Anisotropy of Shale Park, B.; Min, K-B.

Discrete Element Modeling of Transversely Isotropic Rock

Applied to Foundation and Borehole Problems

Scarpato, D.J. KEYNOTE

Constructibility Challenges for Perimeter Control Blasting and Slope Development in Shale and Other "Weak" Rocks

\subsection{Mining and Tunnels}

\section{Murphy, M.M. KEYNOTE}

Shale Failure Mechanics and Intervention Measures in Underground Coal Mines: Results from 50 Years of Ground Control Safety Research

Lisjak, A.; Mahabadi, O.K.; Grasselli, G.; Marschall, P.; Müller H. R.; Garitte, B.; Vietor, T.

The Excavation Damaged Zone in Clay Shales: New Rock Mechanics Insights from Discontinuum Numerical Modelling

Wild, K.M.; Amann, F.; Martin, C.D.

Some Fundamental Hydro-Mechanical Processes Relevant for Understanding the Pore Pressure Response Around Excavations in Low Permeable Clay Rocks
Armand, G.; Noiret, A.; Morel, J.

Pore Pressure Change During the Excavation of Deep Tunnels in the Callovo Oxfordian Claystone

Guglielmi, Y.; Nussbaum, C.; Henry, P.

Underground Research Laboratories to Characterize Faults in Shales

Steiner, W.; Maquil, R.; Didier, G.

Observations of Swelling and Associated Phenomena in Markusberg Tunnel, Schengen, Luxembourg

Perras, M.A.; Diederichs, M.S.

Observations and Numerical Back Analysis of an Excavation in the Queenstone Mudstone

Martin, C. Derek, KEYNOTE

Behaviour of Shales in Underground Environments

\subsection{Hydrocarbon}

Yang, Y.; Zoback, M. KEYNOTE

Viscoplastic Deformation of the Bakken and Adjacent Formations and Its Relation to Hydraulic Fracture Growth

Yu, Y,J.; Liang, W.G.; Bi, J.L.; Geng, Y.D.; Zhang, C.D.; Zhao, Y.S.

Thermophysical Experiment and Numerical Simulation of Thermal Cracking and Heat Transfer for Oil Shale

Shitrit, O.; Rosenberg, Y.O.; Hatzor, Y.H.; Reznik, I.; Nguyen, S.; Feinstein, S.; Vinegar, H.J.

Constitutive Model for Mechanical Properties of Highly Porous Organic-Rich Chalks from Central Israel Hayatdavoudi, A.; Chitila, D.; Boukadi, F. Effect of Cyclic Temperature Propagation in Shale

Nikolinakou, M.A.; Flemings P.G.; Hudec, M.R. KEYNOTE

Modeling of Shales in Salt-Hydrocarbon Systems

Jin, W.; Xu, H.; Arson, C.

Finite Element Simulation of Anisotropic Damage around Pressurized Boreholes in Prefractured Shale

Hayatdavoudi, A.; Sawant, K.G.; Boukadi, F.

A Chemo-Physical Model for Predicting Post-Fracking Pressure Build-Up in Pierre Shale

Li, Q.; Li, X.Y.; Lei, X.-L

Effects of Confining Pressure on Hydraulic Fracturing of Shales by Acoustic Emission Monitoring and X-Ray Computer Tomography

Papachristos, E.; Donzé, F.-V.; Chareyre, B.; Scholtès, L.; Pourpak, H.

Hydraulic Fracturation Simulated by 3D Coupled HMDEM Model

Viegas, G.; Urbancic, T.; Baig, A.; von Lunen, E. 
Rupture Dynamics and Source Scaling Relations of Microseismic Hydraulic Fractues in Shale Reservoirs

Burghardt, J.; Desroches, J.; Lecampion, B.; Stanchits, S.;

Surdi, A.; Whitney, N.; Houston, M.
Laboratory Study of the Effect of Well Orientation, Completion Design and Rock Fabric on Near-Wellbore Hydraulic Fracture Geometry in Shales 